\title{
ПРОКУРОРСЬКИЙ НАГЛЯД ЗА ДОДЕРЖАННЯМ СЛІДЧИМ ЗАКОНІВ ПІД ЧАС ПРОВЕДЕННЯ ДОСУДОВОГО РОЗСЛІДВАННЯ
}

\author{
БУРЛАКА Ярослав Анатолійович - аспірант Харківського національного \\ університету внутрішніх справ \\ https://orcid.org/0000-0003-4977-3074 \\ УДК 343.132 (477) \\ DOI 10.32782/NP.2020.4.14
}

Стаття присвячена вивченню особливостей прокурорсъкого нагляду за додержанням слідчим законів під час проведення досудового розслідування. Аналізується чинне кримінальне процесуальне законодавства, наукові позииіи вчених $i$ правозастосовна практика. Аргументується, що в сучасних умовах правозастосування положень КПК України прочесуальна самостійність слідчого доволі обмежена прочесуальним керівництвом прокурора за досудовим розслідуванням. Наведені законодавчі положення, що стосуються доручень та вказівок прокурора, які можуть надаватися слідчому в кримінальному провадженні. За результатами дослідження робиться висновок про те, що виключно збалансованість повноважень прокурора і слідчого у кримінальному провадженні дасть змогу досягнути повноти і неупередженості проведення досудового розслідування, а отже й якнайкраше реалізувати завдання кримінального провадження.

Ключові слова: прокурор, прочесуальний керівник, слідчий, процесуальна самостійність.

Постановка питання
Процес реформування

інституції в орган, який відповідатиме європейським стандартам [1]. Крім того, у пункті 22Рекомендації Комітету Міністрів Ради Европи щодо ролі прокуратури в системі кримінального правосуддя від 06.10.2000 № 19 вказується про необхідність вживання державою заходів щодо забезпечення прокуратури можливістю надавати поліції інструкції для ефективного застосування пріоритетів політики стосовно запобігання злочинності [2]. Зазначені положення зобов’язують прокуратуру забезпечувати законність діяльності поліції щодо виявлення ознак кримінального правопорушення безпосередньо під час досудового розслідування. В цьому аспекті важливе значення має $\mathrm{i}$ Рекомендація ПАРЕ «Про роль служби публічних обвинувачів у демократичному суспільстві, основаному на верховенстві праві» від 27.05.2003 № 1604, в якій наголошується на ролі прокурора як процесуального керівника під час досудового розслідування [3]. В цьому контексті виникає необхідність розглянути зміст і сутність такого інституту кримінального процесу як прокурорський нагляд за додержанням слідчим законів під час проведення досудового розслідування та його вплив на процесуальну самостійність слідчого.

Стан наукової розробленості проблеми Різновекторні питання, пов'язані $з$ прокурорським наглядом за додержанням слідчим законів під час проведення досудового розслідування, досліджувалися у наукових 
працях багатьох учених. Серед них варто відмітити таких, як В. Бабкова, О. Баулін, Ю. Бєлоусов, В. Венгер, А. Михайлюк, Мілько В., А. Орлеан, А. Палюх, В. Сущенко, С. Шейфер, В. Юрчишин, В. Яворська та ін. Тим часом, практичне застосування положень КПК України свідчить про необхідність переосмислення цього питання, напрацювання рекомендацій з удосконалення чинного законодавства.

\section{Виклад основного матеріалу}

Аналіз визначених у КПК України повноважень прокурора дозволяє стверджувати, що вони є не тільки владними, а й владно-розпорядчими і за своїм змістом спрямовані на утвердження міжнародної практики щодо активної ролі прокурора у кримінальному процесі [4, с. 27; 5, с. 282]. Усі вказівки, доручення, вимоги та процесуальні рішення прокурора мають для органів досудового розслідування обов'язковий характер і за своєю сутністю є процесуальнокерівними [6, с. 71-72]. Відповідно до вимог законодавства така діяльність прокурора на стадії досудового розслідування пов'язана зі здійсненням функції процесуального керівництва.

Із системного аналізу КПК України можна побачити, що два процесуально самостійних учасника, які, до речі, 6 представниками сторони обвинувачення, не є рівноправними між собою за обсягом своїх повноважень. I це пояснюється завданнями кримінального провадження, що передбачені для кожного з них. Природньо, що прокурор, як процесуальний керівник, має можливість впливати на процесуальну діяльність слідчого. Питання залишається відкритим тільки щодо меж такого впливу, адже все частіше з боку прокурора можемо спостерігати надмірне «опікування» за діяльністю слідчого. Про негативні результати зловживання впливом на слідчого з боку прокурора свідчить і судова практика. Натомість, ще свого часу С. А. Шейфер наголошував на необхідності обмежити процесуальне керівництво лише функцією нагляду за слідством. Тобто контролем за законністю та своєчасністю здійснення процесуальних дій і рішень, зокрема, без права втручатися у сферу організації слідчої роботи, за кінцеві результати якої прокурор не може відповідати [7, с. 137]. Водночас саме прокурор зобов'язаний визначати під час досудового розслідування такі ознаки зібраних доказів як достовірність та допустимість задля обгрунтування підозри та доведення в суді винуватості обвинуваченої особи. Відтак саме прокурор має визначати напрям досудового розслідування з можливістю особистої участі в проведенні процесуальних дій для отримання доказів.

Як вважає К. Сляднєва, процесуальна самостійність прокурора реалізується під час всього досудового розслідування кримінального провадження, наприклад, шляхом надання доручень, вказівок, особистої участі в проведенні процесуальних дій, самостійного подання клопотань. Такі повноваження прокурора, визначені у ч. 2 ст. 36 КПК України, як, наприклад, погодження клопотань слідчого, скасовування незаконних та необгрунтованих постанов слідчих, пред'явлення цивільного позову тощо, дещо обмежують самостійність прокурора, оскільки випливають 3 уже вчинених дій, бездіяльності або прийнятих рішень уповноважених осіб [8, с. 177]. Цілком аргументованою видається критика зазначеної позиції О. В. Бауліна, який зазначив, що вона не враховує як «універсальний характер цих повноважень», так і правову природу процесуальної самостійності учасника кримінального провадження, основу якої завжди становить наявність у суб'єкта повноважень самостійно проводити процесуальні дії й ухвалювати рішення на підставі власної оцінки доказів [9]У свою чергу, В. М. Юрчишин наполягає на тому, що функції нагляду і процесуального керівництва $є$ взаємопов'язаними, але не замінюють одна одну. Їх наявність зумовлюється специфікою досудового провадження, необхідністю забезпечення неухильного додержання законності в ньому та якість розслідування кримінальної справи [4, с. 28]. Як бачимо, більшість учених припускає можливість суміщення в повноваженнях прокурора функцій прокурорського нагляду і процесуального керівництва, що протирічить положенням приведеної вище Концепції, де функція процесуального керівництва від- 


\section{Кримінальне право, кримінальний процес та криміналістика}

окремлена від інших функцій, покладених на прокурора у кримінальному провадженні. На наше переконання, процесуальне керівництво досудовим розслідуванням є самостійною функцією прокурора, спрямованою на визначення напрямів досудового розслідування, координацію процесуальних дій та створення умов для належного функціонування слідчих з метою забезпечення швидкого, повного і неупередженого розслідування.

Окремо зупинимось на такій законодавчій вимозі, як незмінність прокурора у кримінальному провадженні. Така гарантія є запорукою єдності між слідчим та процесуальним керівником у напрямі здійснення ефективного розслідування.

У положенні ст. 37 КПК України визначено вичерпний перелік випадків здійснення повноважень прокурора в цьому самому кримінальному провадженні іншим прокурором. За таких обставин подальший рух та його наслідки для кримінального провадження залежить від особи, необізнаної в особливостях уже проведеного досудового розслідування.

Однією $з$ таких підстав $є$ неефективне досудове розслідування або неефективне здійснення прокурором нагляду за дотриманням законів під час проведення досудового розслідування. При цьому ні в КПК України, ні в інших джерелах кримінального процесуального законодавства не визначені критерії оцінки ефективності досудового розслідування. Аише наказом Генеральної прокуратури від 28.03.2019 р. № 51 вказано на критерії, що враховуються під час вирішення питання про відсторонення слідчого від досудового розслідування та призначення іншого слідчого, доручення здійснення досудового розслідування іншому органу досудового розслідування в разі неефективного його проведення [10]. До них відносяться: незабезпечення виконання завдань кримінального провадження; порушення загальних засад кримінального провадження, що негативно може вплинути на всебічність та повноту розслідування; низька якість процесуальної діяльності слідчого (слідчої групи), унаслідок чого отримані результати такої діяльності не відповіда- ють обгрунтовано допустимим результатам, які об'єктивно могли бути досягнуті за цей час з огляду на складність і специфіку розслідування кримінального правопорушення. Відсутність встановленої на рівні закону процедури оцінювання ефективності роботи прокурора під час здійснення процесуального керівництва посилює інколи не виправданий суб'єктивний підхід з боку керівника органу прокуратури, а також підвищує рівень загрози прийняття упередженого й необ'єктивного рішення про заміну процесуального керівника на цій підставі. Вбачається, що за наявності подібних критеріїв повинно вирішуватись питання про визначення ефективності здійснення прокурором нагляду за дотриманням законів під час проведення досудового розслідування.

Наступною підставою для заміни прокурора у кримінальному провадженні є задоволення заяви про його відвід, тяжка хвороба, звільнення $з$ органу прокуратури або інша поважна причина, що унеможливлює його участь. Також існують й інші, не передбачені законом причини, наприклад, заміна процесуального керівника через надмірну завантаженість прокурорів. Протягом 2016-2017 років за ініціативи Міжнародного фонду «Відродження» дослідники з Експертного центру 3 прав людини в межах дослідження «Роль прокурора на досудовій стадії кримінального процесу»вивчили реальну практику прокурорів, іiї ефективність та відповідність законодавству і міжнародним стандартам на основі внутрішніх даних правоохоронної системи. Було встановлено, що переважно у 70 \% випадків погоджує (складає) повідомлення про підозру та клопотання про обрання запобіжного заходу той самий прокурор, який потім 6 присутнім на судовому засіданні під час розгляду такого клопотання. В 11\% досліджених випадків під час розгляду в суді клопотання про обрання запобіжного заходу був присутній прокурор, який не погоджував повідомлення про підозру. Майже у кожному п’ятому випадку (18\%) на судовому засіданні був присутній прокурор, який не погоджував ані повідомлення про підозру, ані навіть саме клопотання про обрання запобіжного заходу. Серед причин частої заміни проку- 
рорів у межах одного кримінального провадження зазначено надмірне навантаження, через яке прокурор фізично не встигає бути присутнім на всіх судових засіданнях. На цю причину також впливає фактор віддаленості судів від обласного центру, що змушує витрачати багато часу на проїзд та участь у судовому засіданні. Задля формального забезпечення принципу незмінності прокурора набула значного поширення практика створення груп прокурорів у кожному кримінальному провадженні, за умови, що створення груп процесуальних керівників у ч. 1 ст. 37 КПК України передбачено як виняток із загального правила індивідуального керівництва досудовим розслідуванням. За даними дослідження цей механізм є недостатньо ефективним, адже у будь-якому разі вся відповідальність покладена на старшого групи прокурорів, а всі інші члени групи виявляються необізнаними 3 матеріалами конкретного кримінального провадження та ходом досудового розслідування [11].

Нагляд прокурора за законністю виконання слідчим будь-якої процесуальної дії або прийняття будь-якого процесуального рішення відбувається постійно й безперервно. Безперервність прокурорського нагляду забезпечена його включенням (нагляду) у безперервну динамічну кримінальну процесуальну діяльність. Це надає прокурору реальну можливість для своєчасного (негайного) виявлення будь-яких порушень закону, від яких би учасників досудового розслідування вони не виходили [12, с. 110]. Реалізація прокурором повноважень на стадії досудового розслідування (п. 4, 5 ч. 2 ст. 36 КПК) унеможливлюється, якщо останній безпосередньо не бере участь у досудовому розслідуванні. Тож, як відзначив свого часу M.I. Мичко, «... прокурор в данной сфере (кримінальна прощесуальна діяльність - авт.) не пассивный наблюдатель за деятельностью следователя и дознавателя, а активный участник предварительного следствия. Он не только следит за тем, чтобы следователь и дознаватель при выполнении следственных мероприятий действовали в рамках дозволенного, хотя это являться его важнейшей задачей, но одновременно присущими ему средствами прокурор содействует раскры- тию преступления, исполнению требований закона о всестороннем, полном и объективном исследовании всех обстоятельств дела. С этой целью он может участвовать в проведении следственных действий, давать следователю и дознавателю обязательные для них указания, проверять их исполнение и т. п.» [13, с. 104-105]. Тільки за безпосередньої участі в провадженні важливих слідчих (розшукових) дій, своєчасного виправлення помилок, допущених при розслідуванні, прокурор може забезпечити його об'єктивність, повноту і всебічність, а отже, і як державний обвинувач твердо і послідовно відстоювати в суді винуватість підсудного.

Труднощі процесуального характеру, що мають місце сьогодні, на практиці свідчать про поверхневе ставлення до своїх обов'язків як слідчими, так, на жаль, і прокурорами. Причинами, що пояснюють таке явище, $\epsilon$ недостатній рівень правової та службової обізнаності цих учасників. Розуміючи керівну роль прокурора у кримінальному провадженні, законодавець наділив його владно-розпорядчими повноваженнями, без яких процесуальне керівництво не може бути ефективним, при цьому залишивши без уваги таку складову компоненту правового статусу прокурора, як його досвід та компетентність.

Аналіз положень ч. 2 ст. 36 та ч. 2 ст. 40 КПК України, а також результати опитування слідчих Національної поліції дозволяє стверджувати, що співвідношення повноважень прокурора як процесуального керівника 3 процесуальною самостійністю слідчого проявляються у випадках тотожності їх повноважень. Зокрема, п. 4 ч. 2 ст. 36 КПК України та п. 2 ч. 2 ст. 40 КПК України співвідносяться між собою в частині проведення слідчих (розшукових) дій, негласних слідчих (розшукових) дій та інших процесуальних дій слідчим самостійно, за вказівкою або дорученням прокурора та особисто прокурором.

Повноваження щодо доручення слідчому проведення у встановлений прокурором строк слідчих (розшукових) дій, негласних слідчих (розшукових) дій, інших процесуальних дій або надання вказівок щодо їх проведення чи брати участь у них, а в не- 


\section{Кримінальне право, кримінальний процес та криміналістика}

обхідних випадках особисто проводити їх прокурор може використовувати при реалізації будь-якої своєї основної чи додаткової функції. Відповідно, слідчий зобов’язаний виконувати письмові доручення та вказівки прокурора, наслідком невиконання яких 6 передбачена законом відповідальність (ч. 4 ст. 40 КПК України). Шляхом надання письмових вказівок та доручень слідчому прокурор здійснює опосередковане процесуальне керівництвом розслідуванням. Втручання прокурора у процесуальну діяльність слідчого повинно бути доцільним і здійснюватися саме під час досудового розслідування, а не тільки у зв'язку з порушенням закону, про що свого часу зазначала А. І. Долгова [14, с. 54]. Звідси можемо констатувати, що процесуальне керівництво полягає в тому, що прокурор і організовує, і контролює діяльність слідчого для встановлення всіх обставин вчиненого кримінального правопорушення, у тому числі, шляхом надання доручень. Відображенням вказаного є зміст пункту 3 Розділу IV наказу Генеральної прокуратури України від 28.04.2019 р. № 51, яким зобов'язано прокурора у кримінальному провадженні при здійсненні ним процесуального керівництва досудовим розслідуванням контролювати виконання доручень i вказівок, наданих слідчому щодо проведення слідчих (розшукових) дій, негласних слідчих (розшукових) дій, інших процесуальних дій [10].

Аналіз положень КПК України, в яких йдеться про надання прокурором доручень слідчому, свідчить про те, що таке повноваження передбачено у випадках: 1) п. 4 ч. 2 ст. 36 КПК України (письмові вказівки щодо доручення слідчому, органу досудового розслідування проведення у встановлений прокурором строк слідчих (розшукових) дій, негласних слідчих (розшукових) дій, інших процесуальних дій; 2) ч. 1 ст. 253 КПК України (доручення слідчому про письмове повідомлення осіб, конституційні права яких були тимчасово обмежені під час проведення негласних слідчих (розшукових) дій, а також підозрюваного, його захисника);3) ст. 259 КПК України (доручення слідчому про забезпечення збереження інформації, отриманої внаслідок втручання у приват- не спілкування, або певного ії фрагменту);4) ч. 1 ст. 290 КПК України (доручення слідчому повідомити підозрюваному, його захиснику, законному представнику та захиснику особи, стосовно якої передбачається застосування примусових заходів медичного чи виховного характеру, про завершення досудового розслідування та надання доступу до матеріалів досудового розслідування); 5) ч. 7 ст. 290 КПК України (доручення слідчому повідомити потерпілого про відкриття матеріалів кримінального провадження). Як бачимо, прокурор уповноважений делегувати частину власних повноважень слідчому без зазначення підстав для цього, обмежуючи останнього оскаржити такі доручення. Така ситуація, на нашу думку, має ознаки необгрунтованого впливу на процесуальну самостійність слідчого, внаслідок чого на практиці прокурор майже не здійснює перераховані вище повноваження самостійно.

Таким чином, письмове доручення прокурора - це процесуальне рішення, яким прокурор зобов'язує слідчого, дізнавача, керівника органу досудового розслідування, оперативні підрозділи провести у встановлений ним строк певні слідчі (розшукові) дії, негласні слідчі (розшукові) дії та інші процесуальні дії. Принципова різниця між дорученням і вказівками в тому, що дії, вчинення яких вимагає прокурор від слідчого у вказівках, можуть вчинятись слідчим і без вказівки прокурора.

3 приводу вказівок прокурора слідчому зазначимо, що в КПК України конкретних підстав для їх надання також не передбачено. Вивчення матеріалів кримінальних проваджень призвело до висновку, що вказівки прокурора стосуються: обрання, зміни або скасування заходів забезпечення кримінального провадження; кваліфікації кримінальних правопорушень; проведення окремих слідчих (розшукових) або негласних слідчих (розшукових) дій, тощо.

Відмітимо, що процесуальна самостійність слідчого передбачає певну свободу у виборі, послідовності та тактиці проведення процесуальних дій. Однак, надання прокурором слідчому вказівок щодо проведення процесуальних дій зобов'язує останнього їх виконувати. I хоча у КПК України не пе- 
редбачено оскарження вказівок прокурора, слідчий має можливість діяти у спосіб, визначений у ст. 311 КПК України і, вважаючи вказівки процесуальним рішенням прокурора, оскаржувати їх прокурору вищого рівня. Тим часом, законодавець передбачив положення, згідно з яким оскарження вказівок прокурора не зупиняє їх виконання, що суттєво обмежує процесуальну самостійність слідчого. 3 іншого боку, неналежне виконання вимог прокурора може призвести до неповноти досудового розслідування, істотних порушень закону, що в подальшому негативно вплине на підтримання державного обвинувачення в суді.

Вважаємо, що тільки збалансована і заснована на дотриманні вимог КПК України взаємодія слідчого і прокурора дозволить пропорційне забезпечення їх процесуальної самостійності, при цьому із залишенням керівної ролі прокурора, що пояснюється його незмінністю у кримінальному провадженні і необхідністю підтримання державного обвинувачення у суді.

Щодо особистої участі прокурора у проведенні процесуальних дій, то це є складовою процесуального керівництва досудовим розслідуванням. Безумовно, швидкість, повнота і неупередженість розслідування, а також дотримання прав, свобод та законних інтересів учасників провадження не можуть бути забезпечені прокурором, якщо він обмежується перевіркою кримінальних проваджень лише під час їх надходження 3 підсумковим процесуальним рішенням. Практика вимагає від прокурора уваги до якості слідства вже під час розслідування, орієнтує його на активне керівництво доказовою діяльністю [15, с. 479].Тобто «необхідний випадок» особистої участі прокурора в кримінальному провадженні настає під час такого стану досудового розслідування, коли слідчий мав можливість або був зобов'язаний, але не провів необхідну процесуальну дію, про що було зазначено у вказівці прокурора, направленій слідчому.

\section{Висновки}

3 урахуванням законодавчих положень алгоритм дій прокурора щодо його особистої участі в проведенні процесуальних дій:розпочато кримінальне провадження, у якому слідчому доручено проведення досудового розслідування;визнання прокурором зібраних у кримінальному провадженні доказів недостатніми та надання вказівок слідчому щодо проведення у встановлений строк слідчих (розшукових) дій, негласних слідчих (розшукових) дій, інших процесуальних дій;визнання досудового розслідування неефективним у разі ігнорування слідчим таких вказівок; з метою забезпечення швидкого, повного та неупередженого розслідування особисте проведення слідчих (розшукових) та процесуальних дій.

На наш погляд, такий алгоритм забезпечить реалізацію процесуальної самостійності прокурора без зайвого впливу на процесуальну самостійність слідчого. Пояснюється це тим, що за результатом проведеного досудового розслідування саме прокурор звертається до суду з обвинувальним актом, клопотанням про застосування примусових заходів виховного чи медичного характеру, відповідно, відповідальність за якість проведеного досудового розслідування покладається не на слідчого, а тільки на прокурора. Таким чином, брати участь у проведенні досудового розслідування шляхом особистого здійснення процесуальних дій прокуророві необхідно тільки у випадку, коли він не в змозі іншими засобами забезпечити вирішення завдань розслідування.

\section{Мітература}

1. Висновок № 190 (1995) Парламентської Асамблеї Ради Европи щодо заявки України на вступ до Ради Европи : Страсбург, 26 вересня 1995 року. URL: https:// zakon.rada.gov.ua/laws/show/994_590\#Text.

2. Рекомендація Rec (2000) 19 Комітету Міністрів Ради Европи державам-членам щодо ролі прокуратури в системі кримінального правосуддя від 06.10.2000. URL: https://supreme.court.gov.ua/userfiles/ Rec_2000_19_2000_10_6.pdf

3. Рекомендації ПАРЕ «Про роль служби публічних обвинувачів у демократичному суспільстві, основаному на верховенстві праві» від 27.05.2003 № 11. URL: https:// www.coe.int/T/r/Parliamentary Assembly/[Russian documents]/ [2003]/Rec1604.asp 


\section{Кримінальне право, кримінальний процес та криміналістика}

4. Юрчишин В.М. Прокурор як керівник досудового розслідування. Адвокат. 2012.№ 7(142). С. 26-30.

5. Михайлюк А. Організаційно-правові засади процесуального нагляду за дотриманням законності на стадії досудового розслідування. Підприємниитво, господарство $i$ право. 2019. № 6. С. 281-286.

6. Бабкова В.О. Проблеми здійснення прокурором наглядових повноважень у формі процесуального керівництва під час проведення досудового розслідування. $\mathrm{Bi}$ сник Національної академії прокуратури України. 2012. № 3. С. 71-72.

7. Шейфер С. А. О формах осуществления прокурорского надзора в уголовном судопроизводстве. Прокуратура в системе политических и правовъгх институтов общества. М.: ВНИИПП, 1994. 137 с

8. Сляднева К.А. Самостійність та незмінність як диспозитивні засади діяльності прокурора у кримінальному провадженні Jurnalul juridic național: teorie şi practică Publicație ştiințifi co-practică de drept. (2018) 2-1(30). URL: www.jurnaluljuridic.in.ua/archive/2018/2/ part_1/39.pdf

9. Баулін О.В. Правові санкції, примус і відповідальність як гарантії процесуальної самостійності прокурора у досудовому кримінальному провадженні. Вісник національної академії прокуратури України. № 3 (2019). С. 79-94.

10. Про затвердження Порядку організації діяльності прокурорів і слідчих органів прокуратури у кримінальному провадженні: наказ Генеральної прокуратури від 28.03.2019 № 51 // База даних «Законодавство України» / ВР України. URL: https:// zakon.rada.gov.ua/laws/show/z0363-19\#Text

11. Бєлоусов Ю., Венгер В., Мілько В., Орлеан А., Сущенко В., Яворська В. Прокурор: керує? наглядає? розслідує?: звіт за результатами дослідження «Роль прокурора на досудовій стадії кримінального процесу» /

\section{SUMMARY}

The article is devoted to the study of the peculiarities of prosecutorial supervision over the observance of laws by investigators during the pretrial investigation. The current criminal procedural legislation, scientific positions of scientists and law enforcement practice are analyzed. It is argued that in the current conditions of law enforcement of the provisions of the CPC of Ukraine, the procedural independence of the investigator is quite limited by the procedural guidance of the prosecutor in the pre-trial investigation. The legislative provisions concerning the instructions and instructions of the prosecutor which can be given to the investigator in criminal proceedings are resulted. According to the results of the study, it is concluded that only a balanced balance of powers between the prosecutor and the investigator in criminal proceedings will allow to achieve completeness and impartiality of the pre-trial investigation, and thus best implement the tasks of criminal proceedings.

Key words: prosecutor, procedural manager, investigator, procedural independence.

за заг. ред. Бєлоусова Ю. К.: СТ-Друк, 2017. 268 c.

12. Юрчишин В. М. Процесуальні функції прокурора у досудовій стадії кримінального провадження: поняття, призначення, система: навчальний посібник. Чернівці: Технодрук, 2014. 276 с.

13. Мычко Н. И. Прокуратура Украины: роль и место в системе государственной власти Донецк: Донеччина, 1999. 256 с.

14. Долгова А. И. Формы прокурорского надзора. Вопросы прокурорского надзора: сб. науч. тр. М., 1972. С. 51-54.

15. Палюх А. Процесуальне керівництво як основа доказової діяльності прокурора під час досудового розслідування. Вісник Нaизонального університету «Һьвівсъка політехніка». Юридичні науки. 2017. № 865. С. 474-482. 